\title{
Grade-Tonnage Models of Chinese Gold Deposits*
}

\section{by Tetsuya SHOJI ${ }^{1}$ and Xianguo MENG $^{2}$}

In order to assess Chinese gold resources, more than 1600 deposits of the primary and placer types have been statistically analyzed. The deposits are classified into three independent groups and two summarized groups: primary-main $(\mathrm{Pm})$, primary-accessory $(\mathrm{Pa})$, placer $(\mathrm{S})$, primary $(\mathrm{P}=\mathrm{Pm}+\mathrm{Pa})$ and all data $(\mathrm{T}=\mathrm{P}+\mathrm{S})$. Gold metal amount shows lognormal distribution in each of the groups. Grade of each of Groups Pm and Pa shows a single population, but that of Group S two populations. The correlation coefficients among grades, metal amounts and tonnages indicate that metal amounts of deposits largely depend on tonnage and scarcely on grades. The grade-cumulative tonnage relation of every group is approximated by the combination of two or three exponential functions. The critical grades of Groups Pm, Pa, and $\mathrm{S}$ are 2.8, 0.20 and $0.10 \mathrm{~g} / \mathrm{t}$ ( or g/ $\mathrm{m}^{3}$ ), respectively. These values suggest that the mines with low grades are operated at the critical condition.

KEY WORDS : Gold, China, Resource, Assessment, Grade, Tonnage

\section{Introduction}

China is one of the most promising suppliers of gold in the world. Several thousand gold deposits including ore spots have been discovered in China. China has rapidly developed them in the two decades, and is becoming one of the main suppliers of gold in the world. This fact suggests that China plays an important role in the world gold supply, and that hence Chinese gold resources should be always taken into consideration of gold economics. It is important, therefore, to assess Chinese gold resources.

Grade-tonnage relations are one of the most useful tools in the resource assessment. For example, Singer and others ${ }^{7)}$ analyzed 267 deposits of porphyry, stratabound and massive sulfide types on the basis of correlation coefficients between logarithmic grades and logarithmic tonnage as well as testing normal and lognormal distributions, and revealed statistical relations between grades and tonnage, and gave some suggestions for exploration. Cox and Singer ${ }^{1)}$ developed the method and applied it to more than 3900 deposits of 89 types in the world, and obtained many suggestive results. Zhou and others ${ }^{8)}$ applied the method to Chinese gold deposits, and revealed relations among grades, tonnages and types.

Shoji ${ }^{25)}$ proposed a model based on a relation between grades and tonnages. According to the model, grade $x(0 \leq x \leq 1)$ and differential ore tonnage $t(x)$ between grades $x$ and $x+d x$ are assumed to have a following relation:

$$
\ln T(x)=\ln T_{0}-x / x_{c}
$$
where

$$
T(x)=\int_{x}^{1} t(x) d x,
$$

differential metal amount $m(x) d x=x \cdot t(x)=x \cdot d T(x) / d x$ has a maximum at $x=x_{c}$ (critical grade). If all operating mines have ore grades higher than the critical grade, $m(x)$ increases with decreasing grade. The resources having such character seem to be optimistic, because more metal is expected by decreasing grade. In contrast, if some mines are working with grades lower than the critical grade, we cannot expect more metal, because $m(x)$ decreases with decreasing grade in the region of $x<x_{c}$. Consequently, such mineral resources are classified as pessimistic. Nickel resources are optimistic, while most of base metals such as copper, lead, zinc, tungsten and molybdenum are pessimistic ${ }^{2)-4)}$

In contrast to base metal resources, the $x-\log T(x)$ relation of gold resources is convex downwards ${ }^{3)}$. This implies that a straight-line fitting the grade-tonnage relation is not obtained on the diagram, and that only a tangent which touches the curve is defined at each grade. The tangent becomes steep with decreasing grade, because the curve is convex downwards. For this reason, the critical grade cannot be defined, and hence gold resources were concluded to be sufficiently optimistic ${ }^{3)}$. However, this conclusion should be revised as stated later.

The present paper applies the grade-tonnage model to Chinese gold deposits, and aims to assess the resources. The data used in this paper were collected mainly from "Series of Geological Memoir" published by Ministry of Geology and Mineral Resources of People's Republic of China, which includes Regional Geology of each province, and Mineral Deposits and Mineral Resources of each province, "The Discovery History of Mineral Deposit of China" compiled by its editorial committee, "Mineral Deposits of China" edited by its editorial committee, and other many published documents such as excursion guidebooks at international meetings. The data are also referred from unpublished sources including personal communications if possible.

\section{Statistical Distributions}

The present data consist of codes, names, localities (prov- 
inces and counties), occurrences (load, accessory, placer, etc.), types (quartz vein, polymetallic deposit, altered rock, etc.), metal amounts (unit: $\mathrm{t}$ ), grades $\left(\mathrm{g} / \mathrm{t}\right.$ or $\mathrm{g} / \mathrm{m}^{3}$ ), scales (small, middle, large, and very large), information quality (exploration, detailed survey, etc.), condition (working, closed, etc.) of 1630 gold deposits. The deposits are genetically classified into two origins: primary and secondary (placer). The occurrence data also suggest that gold is mined as a main or accessory product from the primary origin, while as only a main product from the secondary one. We define three independent groups and two summarized groups: primary-main $(\mathrm{Pm})$, primary-accessory $(\mathrm{Pa})$ and placer (secondary: $\mathrm{S})$, and primary $(\mathrm{P}=\mathrm{Pm}+\mathrm{Pa})$ and all data $(\mathrm{T}=\mathrm{P}+\mathrm{S})$. Table 1 lists the classification of Chinese gold deposits in this paper, and the number of deposits in each category defined by the combination of groups and scales.

According to the data source, primary deposits are divided into four classes on the basis of gold amounts (Table 1), the boundaries are approximately 4, 15 and 30 t. On the other hand, placer deposits are divided into three classes (Table 1), which are separated at about 2 and $7 \mathrm{t}$. If scale classes are not taken into account, gold amount show lognormal distributions not only in each independent group but also in each summarized group (Fig.1). The correlation coefficients between logarithms of gold amount and cumulative frequency, whose actual value

Table 1 Classification of Chinese gold deposits, and the number of deposits in each category by the combination of groups and scales.

\begin{tabular}{|c|c|c|c|c|c|c|c|}
\hline \multirow{2}{*}{ Type } & \multirow{2}{*}{ Product } & \multirow{2}{*}{$\begin{array}{l}\text { Group } \\
\text { Name }\end{array}$} & \multicolumn{4}{|c|}{ Scale } & \multirow{2}{*}{ Total } \\
\hline & & & Small & Middle & Large & V. Large & \\
\hline \multirow[t]{3}{*}{ Primary } & Main & $\mathrm{Pm}$ & 588 & 227 & 47 & 11 & 873 \\
\hline & Accessory & $\mathrm{Pa}$ & 125 & 51 & 14 & 6 & 196 \\
\hline & Subtotal & $\mathrm{P}$ & 713 & 278 & 61 & 17 & 1069 \\
\hline Placer & Main & $\mathrm{s}$ & 404 & 134 & 23 & - & 561 \\
\hline Total & & $T$ & 1117 & 412 & 84 & 17 & 1630 \\
\hline
\end{tabular}

Table 2 Empirical correlation coefficients on lognormal distribution papers (the frequencies are cumulated from the high value side).

\begin{tabular}{|c|c|c|c|c|c|c|}
\hline \multirow{2}{*}{ Type } & \multirow{2}{*}{ Product } & \multirow{2}{*}{$\begin{array}{l}\text { Group } \\
\text { Name }\end{array}$} & \multicolumn{3}{|c|}{ Variable } & \multirow{2}{*}{$\begin{array}{c}\text { Prop. } \\
\%\end{array}$} \\
\hline & & & Gold & Grade & Tonnage & \\
\hline \multirow[t]{3}{*}{ Primary } & Main & $\mathrm{Pm}$ & 0.993 & 0980 & 0.998 & 82 \\
\hline & Accessory & $\mathrm{Pa}$ & 0.995 & 0.995 & 0.993 & 18 \\
\hline & Subtotal & $\mathrm{P}$ & 0.996 & 0.912 & 0.987 & 0.993 \\
\hline \multirow[t]{3}{*}{ Placer } & High & Sh & & 0.992 & & 16 \\
\hline & Low & $\mathrm{SI}$ & & 0.995 & & 84 \\
\hline & Subtotal & s & 0.999 & 0.908 & 0.976 & 0.996 \\
\hline Total & & $T$ & 0.998 & 0.948 & 0.995 & \\
\hline
\end{tabular}

The figures in Prop. represent the main/accessory proportions in the primary type, and the high/low proportions in the pla cer type, and the correlation coefficients between actual and estimated cumulative frequency in each type.

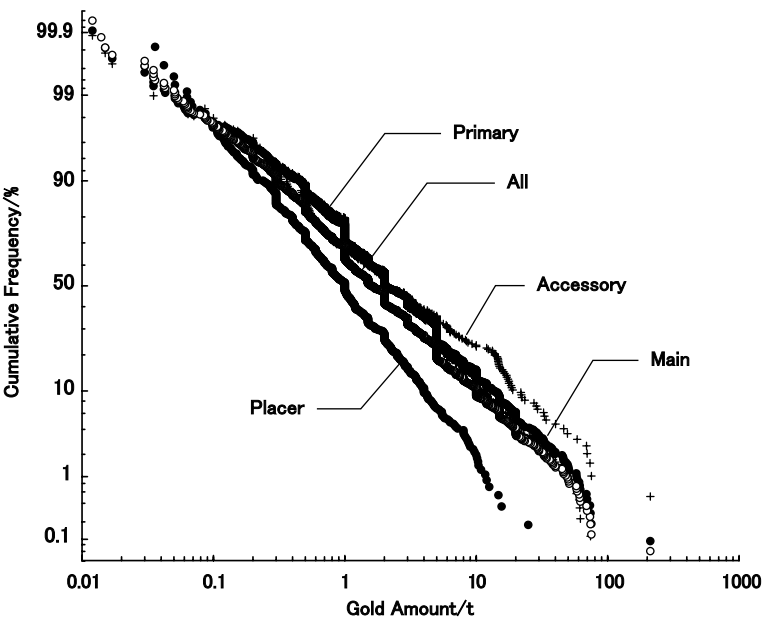

Fig. 1 Lognormal plots of metal amounts of Chinese gold deposits. is given on the basis of the inverse function of normal distribution (let's call this IFND value), are 0.993, 0.995, 0.996, 0.999 and 0.998 in Groups Pm, Pa, P, S and T, respectively (Table 2).

Grade shows lognormal distributions in some groups, but not in the others (Fig.2 and Fig.3). The linearity between logarithmic grade and IFND value is good for Groups Pm and $\mathrm{Pa}$. Their correlation coefficients are 0.980 and 0.995 , respectively (Table 2). In contrast, the correlation coefficient of Group P is 0.912. If Group $P$ is explained by the combination of two lognormal distributions showing Groups $\mathrm{Pm}$ and $\mathrm{Pa}$ with the shares of 82 and $18 \%$, respectively (Fig.2), the estimated frequency correlates to the actual frequency with a coefficient of 0.993 (Table 2). In this case, Group Pm is dominant above the grade of $9 \mathrm{~g} / \mathrm{t}$, while Group $\mathrm{Pa}$ is dominant below the grade. This implies that the grade is applied for the classification of Groups $\mathrm{Pm}$ and $\mathrm{Pa}$ when the groups are not presented.

The relation between logarithmic grade and IFND value of Group S shows a curve convex downwards on the whole (Fig.3). When the relation is approximated by the combination

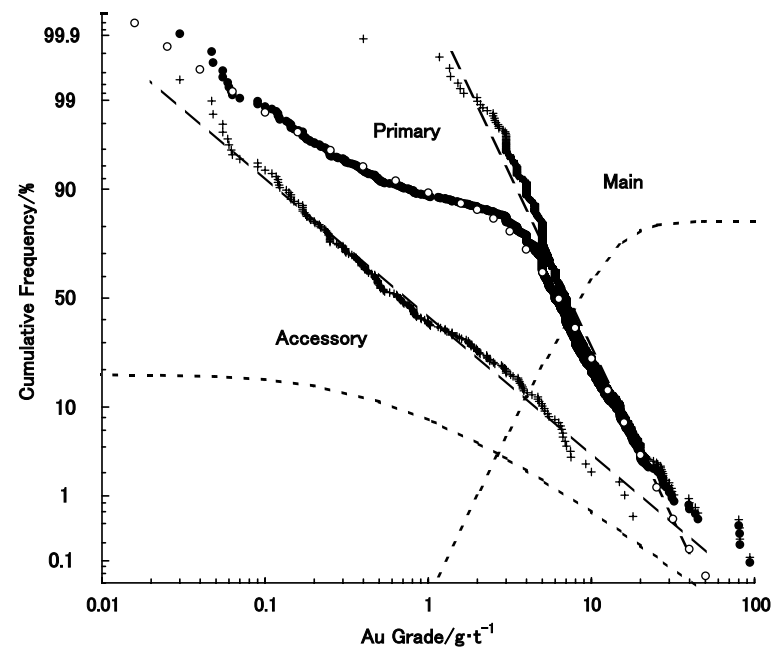

Fig. 2 Lognormal plots of grades of primary gold deposits. Deposits supplying gold as main product and byproduct show different statistical populations. Open circles show the cumulative frequency in the case where the main and accessory gold deposits are combined with proportions of 82 and $18 \%$, respectively.

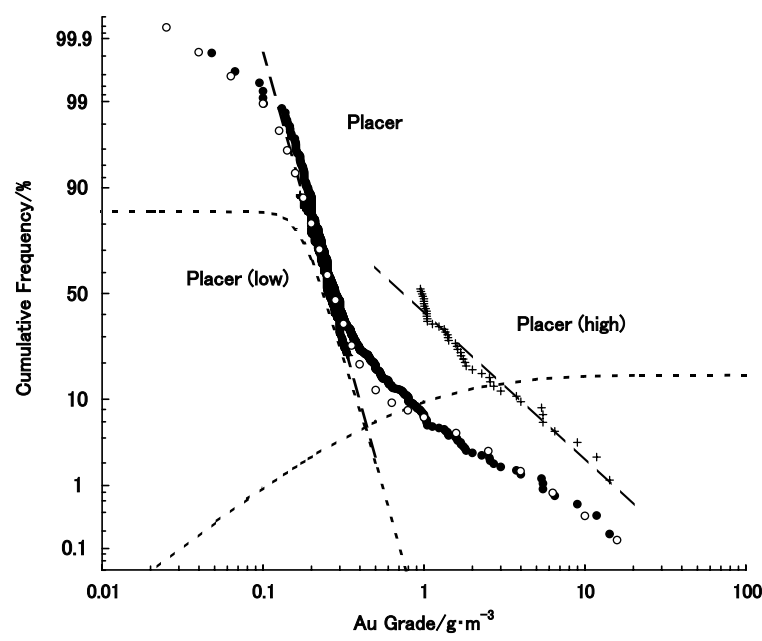

Fig. 3 Lognormal plots of grades of secondary (placer) gold deposits. Deposits of high and low grade show different statistical populations. Open circles show the cumulative frequency in the case where the high and low-grade deposits are combined with proportions of 14 and $86 \%$, respectively. 
of two lognormal distributions, the correlation coefficient between the actual and estimated frequencies is 0.996 (Table 2 ). The shares of the high and low-grade subgroups are 16 and $84 \%$, respectively. The same frequency of both distributions appears at the grade of $0.25 \mathrm{~g} / \mathrm{m}^{3}$. The deposit type is considered to be one of the reasons why placer deposits are divided into two subgroups. The types described for 518 placer deposits are alluvium (482 deposits), alluvium-diluvium (8), alluviumslump (1), diluvium (13), diluvium-slump (1), eluvium (1), eluvium-slump (6), slump (2), terrace (3) and karst (1). If all of the deposits with grades higher than $0.95 \mathrm{~g} / \mathrm{cm}^{3}$ are assumed to belong to the high-grade group, the proportion of the alluvium type is $64 \%(=23 / 36)$. On the other hand, if all of the deposits with grades lower than $0.341 \mathrm{~g} / \mathrm{cm}^{3}$ are assumed to belong to the low-grade group, the proportion of the alluvium type is $98 \%(=323 / 328)$. These facts suggest that the type is not the reason for two populations, because the alluvium type is the most dominant in both groups.

Tonnages are calculated from grade and gold amount data. The frequency can be approximated by a lognormal distribution as that of gold amount (Fig.4). The correlation coefficients between logarithms of tonnages and IFND value are 0.998, 0.993, 0.987, 0.976 and 0.995 for Groups Pm, Pa, P, S and T, respectively (Table 2).

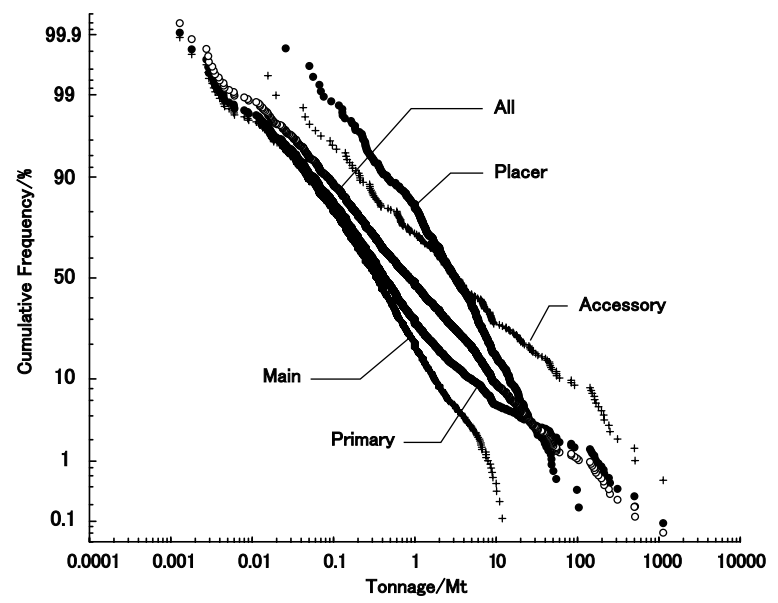

Fig. 4 Lognormal plots of ore tonnages of Chinese gold deposits.

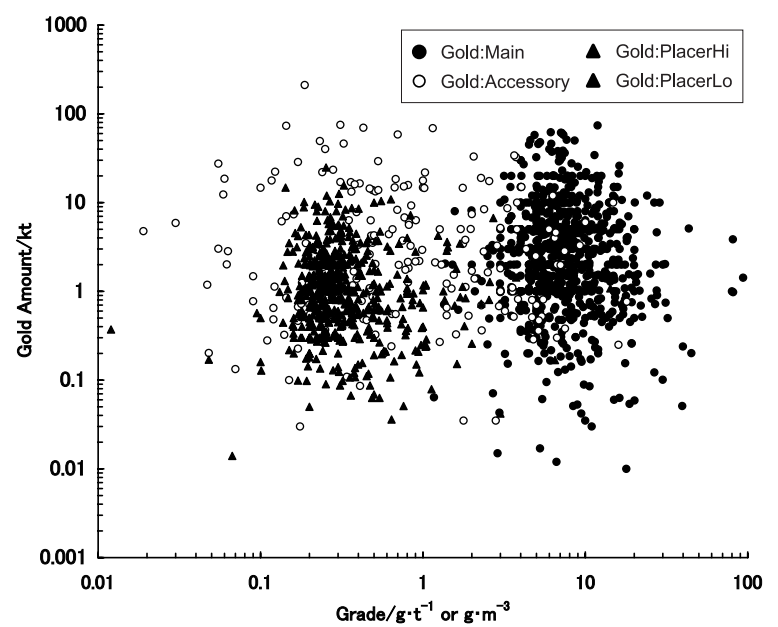

Fig. 5 A scattered diagram of grades and gold amounts of Chinese gold deposits. Groups: $\mathrm{Pm}=$ solid circle, $\mathrm{Ps}=$ open circle, and $\mathrm{S}=$ solid triangle.

\section{Correlations}

Fig. 5 shows relations between grades and gold amounts of Chinese gold deposits. Any group does not show a high correlation. Only Group $\mathrm{T}$ shows very weak correlation $(r=0.2)$. Fig. 6 is a scattered diagram of grades and ore tonnages. Every group shows weak negative correlation. The correlation coefficients are from -0.4 (Group Pm) to -0.7 (Group T). Fig.7 shows relations between tonnages and gold amounts. Every group shows remarkable positive correlation. The correlation coefficient of Group Pm is the highest, and the value is 0.924 . The correlation coefficient of Group $\mathrm{Pa}$ is also high (0.778). Group $\mathrm{S}$ shows high correlation. If Group $\mathrm{S}$ is divided into high and low grade subgroups, the correlation coefficients are 0.848 and 0.957 , respectively. Table 3 summarizes correlation coefficients among grades, gold amounts and ore tonnages in both linear and logarithmic scales.

The high correlation coefficients between tonnages and gold amounts and the low correlation between grades and gold amounts indicate that a gold amount of each deposit is mostly controlled by the tonnage and free from the grade.

\section{Grade-Tonnage Models}

The grade-tonnage diagram of each of Groups Pm, Pa, P,

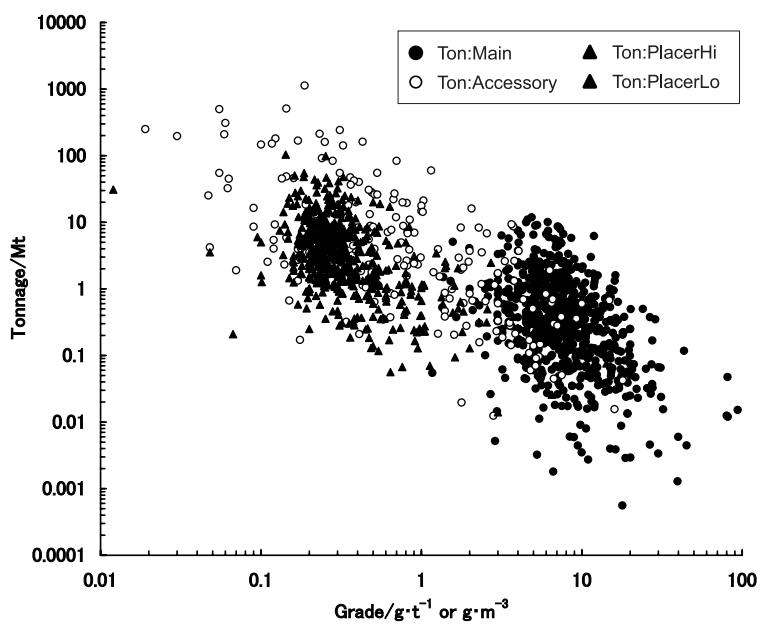

Fig. 6 A scattered diagram of grades and ore tonnages of Chinese gold deposits. Groups: $\mathrm{Pm}=$ solid circle, $\mathrm{Ps}=$ open circle, and $\mathrm{S}=$ solid triangle.

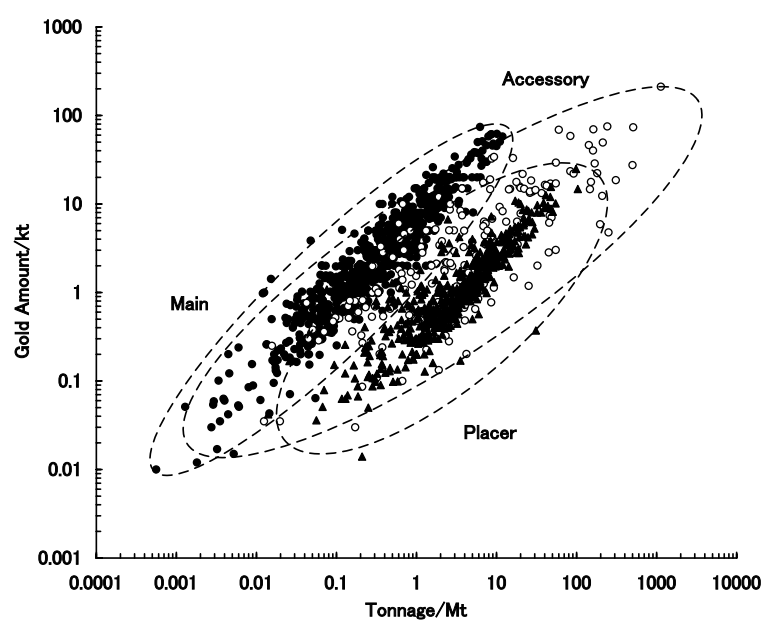

Fig. 7 A scattered diagram of ore tonnages and gold amounts of Chinese gold deposits. $\mathrm{Pm}=$ solid circle, $\mathrm{Ps}=$ open circle, and $\mathrm{S}=$ solid triangle. 
Table 3 Correlation coefficients among grades, gold amounts and ore tonnages in each group.

\begin{tabular}{l|rrrrr}
\hline \multirow{2}{*}{ Relation } & \multicolumn{5}{|c}{ Group } \\
& $\mathrm{Pm}$ & $\mathrm{Pa}$ & $\mathrm{P}$ & $\mathrm{S}$ & \multicolumn{1}{c}{$\mathrm{T}$} \\
\hline & \multicolumn{6}{|c}{ in linear scale } \\
Grade-Gold Amount & -0.054 & -0.115 & -0.092 & -0.006 & 0.020 \\
Grade-Ore Tonnage & -0.173 & -0.172 & -0.126 & -0.135 & -0.109 \\
Ore Tonnage-Gold Amount & 0.913 & 0.838 & 0.643 & 0.881 & 0.634 \\
& \multicolumn{7}{|c}{ in logarithmic scale } \\
Grade-Gold Amount & -0.041 & -0.056 & -0.052 & -0.020 & 0.200 \\
Grade-Ore Tonnage & -0.418 & -0.671 & -0.667 & -0.536 & -0.708 \\
Ore Tonnage-Gold Amount & 0.924 & 0.778 & 0.779 & 0.855 & 0.550 \\
\hline
\end{tabular}

$\mathrm{S}$ and $\mathrm{T}$ was drawn in order to assess its resources (Figs.8-12). In the diagram, the independent variable is grade $x$, and the dependent variable is logarithms of the cumulative tonnage (unit: kt) given by Equation (2). Every grade-tonnage diagram is convex downwards on the whole, and the correlation coefficients between grade and logarithmic cumulative tonnage is higher (lower if absolute values) than -0.9 , such as -0.891 , $-0.897,-0.899,-0.713$ and -0.898 for Groups Pm, Pa, P, S and $\mathrm{T}$, respectively (Table 4).

As shown in Fig.8, the grade-tonnage diagram of Group $\mathrm{Pm}$ is divided into 4 parts, which are separated at grades of 30 ,

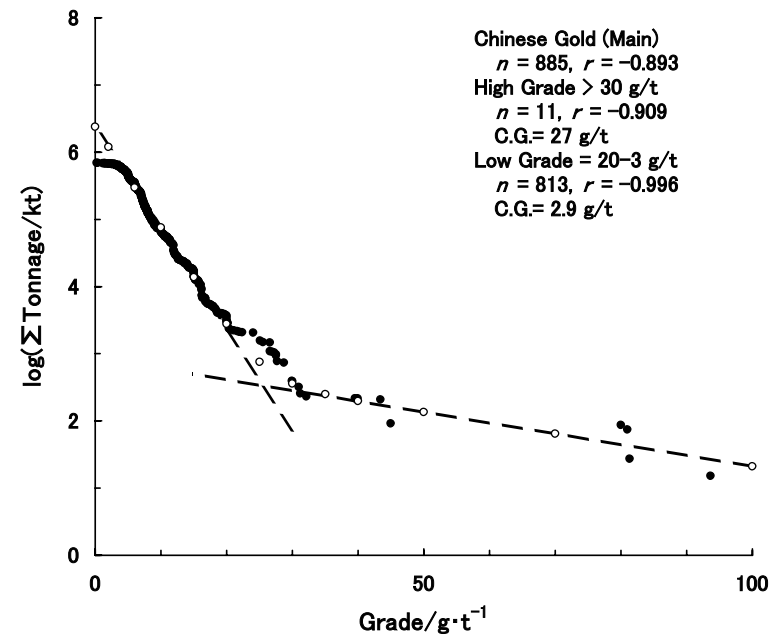

Fig. 8 A grade-cumulative tonnage relation of primary gold deposits whose produce gold as main product. Open circles show the grade-cumulative tonnage relation estimated by Equation (3)

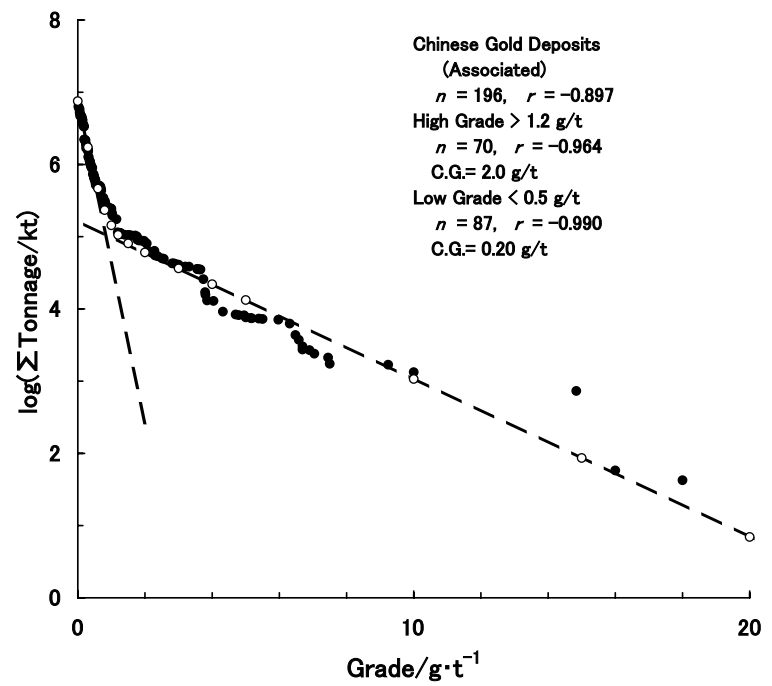

Fig. 9 A grade-cumulative tonnage relation of primary gold deposits whose produce gold as accessory product. Open circles show the grade-cumulative tonnage relation estimated by Equation (4).
20 and $3 \mathrm{~g} / \mathrm{t}$. The high $(>30 \mathrm{~g} / \mathrm{t})$ and middle $(20-3 \mathrm{~g} / \mathrm{t})$ grade parts are linear (the correlation coefficients are 0.909 and 0.996 , respectively). The part between 30 and $20 \mathrm{~g} / \mathrm{t}$ curves, and is con-

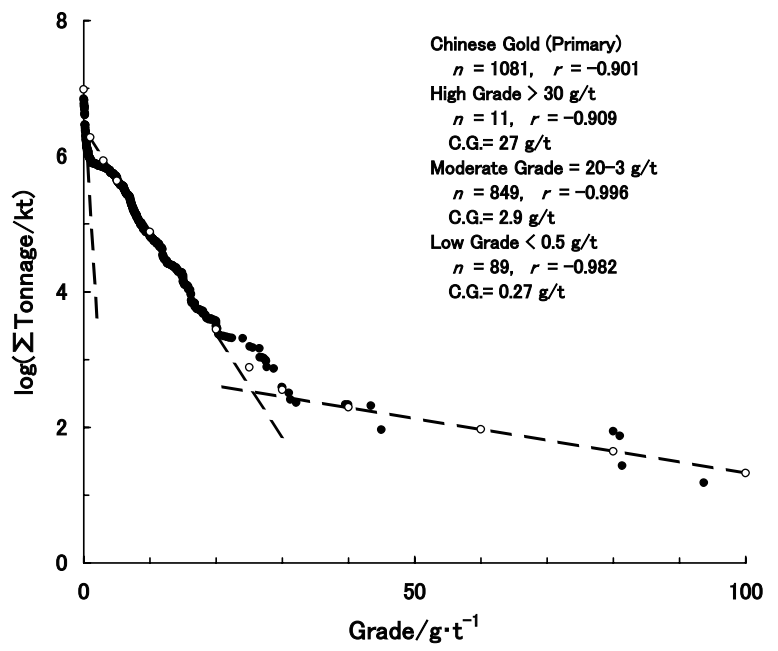

Fig. 10 A grade-cumulative tonnage relation of primary gold deposits. Open circles show the grade-cumulative tonnage relation estimated by Equation (5)

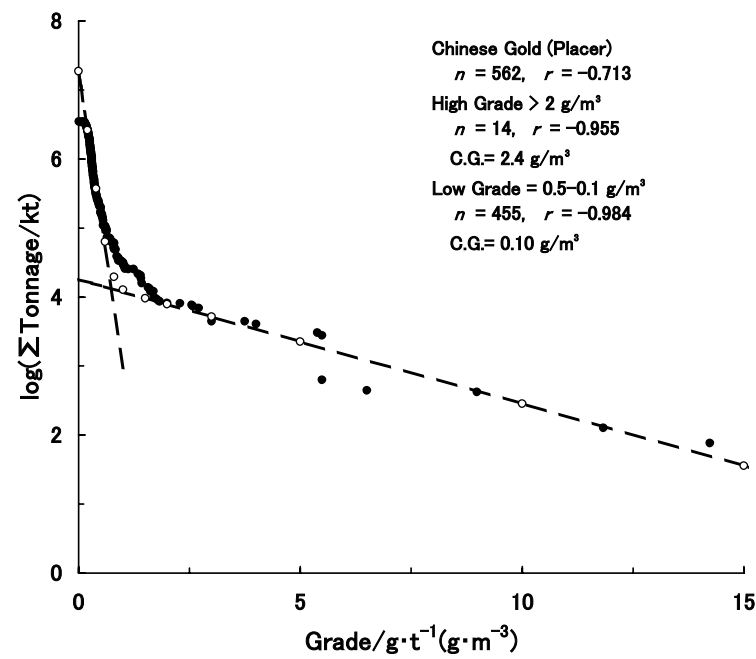

Fig. 11 A grade-cumulative tonnage relation of secondary gold deposits Open circles show the grade-cumulative tonnage relation estimated by Equation (6)

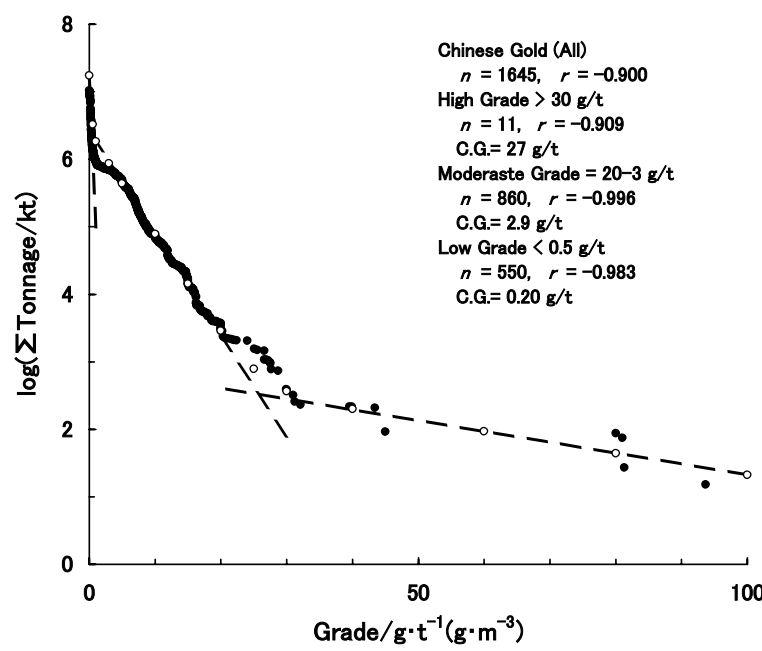

Fig. 12 A grade-cumulative tonnage relation of all Chinese gold deposits. Open circles show the grade-cumulative tonnage relation estimated by Equation (7) 
Table 4 Correlation coefficients between grade and tonnages cumulated from high-grade side, numbers of the functions used for the estimation, correlation coefficients between the actual and estimated cumulative tonnages, and the critical grades of the estimator for the low-grade part.

\begin{tabular}{l|ccccccc}
\hline Group & $\mathrm{Pm}$ & $\mathrm{Pa}$ & $\mathrm{P}$ & $\mathrm{S}$ & $\mathrm{T}$ & $\mathrm{MISm}$ & $\mathrm{MIS}$ \\
\hline Correlation (grade-tonnage) & 0.891 & 0.897 & 0.899 & 0.713 & 0.898 & 0.927 & 0.910 \\
Number of functions for estimation & 2 & 2 & 3 & 2 & 3 & 2 & 3 \\
Correlation (actual -estimated) & 0.995 & 0.991 & 0.991 & 0.987 & 0.993 & 0.990 & 0.990 \\
Critical Grade $/ \mathrm{g} \cdot \mathrm{t}^{-1}$ (or $\mathrm{g} \cdot \mathrm{m}^{-3}$ ) & 2.8 & 0.20 & 0.27 & 0.10 & 0.20 & 3.1 & 1.0 \\
\hline
\end{tabular}

MISm and MIS show the values of mainly Au-producing deposits and Au-Bearing deposits stored in the

Mine Information System of Sumitomo Metal Mining Co., Ltd. (Shoji, 1993), respectively.

sidered to be transitional between both parts. The low $(<3 \mathrm{~g} / \mathrm{t})$ grade part is almost flat in the diagram, suggesting that unminable deposits of low grades have been scarcely reported. If the cumulative tonnage is estimated by the combination of two exponential functions which are obtained from the high and middle grade parts as follows:

$$
\begin{aligned}
T_{\text {Main }} / \mathrm{kt}= & 10^{\wedge}(2.94-0.0162 x)+10^{\wedge}(6.38-0.150 x) \\
= & \exp \{\ln 10 \cdot(2.94-0.0162 x)\} \\
& \quad+\exp \{\ln 10 \cdot(6.38-0.150 x)\}, \cdots \cdots \cdots
\end{aligned}
$$

then the correlation coefficient between the actual and estimated cumulative tonnages is 0.995 including the low-grade part.

Group $\mathrm{Pa}$ is divided into 3 parts, which are separated at grades of 1.2 and $0.5 \mathrm{~g} / \mathrm{t}$ (Fig.9). The cumulative tonnage rapidly increases with decreasing grade in the range less than $0.5 \mathrm{~g} / \mathrm{t}$. This behavior is different from that of Group Pm. When gold is recovered as a byproduct, the mining cost is supplied by the metals of the main product such as copper, zinc, etc. The cumulative tonnage estimated by the combination of two exponential functions approximating the middle $(>1.2 \mathrm{~g} / \mathrm{t})$ and low $(<0.5 \mathrm{~g} / \mathrm{t})$ grade parts correlates linearly to the actual value with the coefficient of 0.998 (Table 4). The equation is as follows:

$$
\begin{aligned}
T_{\text {Accessory }} / \mathrm{kt}=\exp \{\ln 10 \cdot(5.23-0.219 x)\} \\
+\exp \{\ln 10 \cdot(6.87-2.22 x)\} .
\end{aligned}
$$

The definitions of Groups $\mathrm{Pm}$ and $\mathrm{Pa}$ are based on not geology but economics, though each mineral deposit was formed by a geological process. In order to know the relation of grades and tonnages on the geological point of view, accordingly, a grade-tonnage diagram of Group $\mathrm{P}$ is necessary (Fig.10). The diagram has a shoulder between grades of 3 and $1 \mathrm{~g} / \mathrm{t}$, where the slope is gentle. This shoulder is caused by the facts that the numbers of the low grade $(<3 \mathrm{~g} / \mathrm{t})$ deposits of Group Pm is limited, and that the middle grade $(>1.2 \mathrm{~g} / \mathrm{t})$ deposits of Group Pa are not so many. Since Group P is the sum of Groups $\mathrm{Pm}$ and $\mathrm{Pa}$, Group P consists of 6 parts which are separated at 30, $20,3,1.2$ and $0.5 \mathrm{~g} / \mathrm{t}$. However, the boundary of $1.2 \mathrm{~g} / \mathrm{t}$ can be omitted, because the diagram is gentle around the grade. The slope of the diagram becomes rapidly steep with decreasing grade in the range with grade less than $0.5 \mathrm{~g} / \mathrm{t}$. Although the diagram has a shoulder, consequently, the cumulative tonnage of Group P is sufficiently approximated by the combination of three exponential functions showing the high $(>30 \mathrm{~g} / \mathrm{t})$, middle $(20-3 \mathrm{~g} / \mathrm{t})$ and low $(<0.5 \mathrm{~g} / \mathrm{t})$ grade parts as follows (Fig.10):

$$
\begin{aligned}
T_{\text {Primary }} / \mathrm{kt}= & \exp \{\ln 10 \cdot(2.94-0.0162 x)\}+\exp \{\ln 10 \cdot(6.39-0.151 x)\} \\
& +\exp \{\ln 10 \cdot(6.86-1.62 x)\} . \cdots \cdots \cdots \cdots \cdots
\end{aligned}
$$

The correlation coefficient between the actual and estimated values is 0.991 (Table 4).

The grade-tonnage diagram of Group $\mathrm{S}$ is divided into 4 parts, which are separated at grades of $2,0.5$ and $0.1 \mathrm{~g} / \mathrm{m}^{3}$. The low $\left(<0.1 \mathrm{~g} / \mathrm{m}^{3}\right)$ grade part is flat, just like the lowest grade part of Group Pm, corresponding to the unminable grade (Fig.11). The cumulative tonnage can be estimated by the combination of two exponential functions showing the middle $\left(>2 \mathrm{~g} / \mathrm{m}^{3}\right)$ and low grade $\left(0.5-0.1 \mathrm{~g} / \mathrm{m}^{3}\right)$ parts as follows:

$$
\begin{aligned}
T_{\text {Placer }} / \mathrm{kt}=\exp & \{\ln 10 \cdot(4.23-0.180 x)\} \\
+ & \exp \{\ln 10 \cdot(7.27-4.30 x)\}
\end{aligned}
$$

The coefficient between the actual and estimated cumulative tonnages is 0.982 including the lowest grade part (Table 4). The exponential functions applied to the grade-tonnage relation cross at the grade of $0.73 \mathrm{~g} / \mathrm{m}^{3}$. This value is included in the high $\left(>0.25 \mathrm{~g} / \mathrm{m}^{3}\right)$ grade subgroup of Group S.

Group $\mathrm{T}$ is the sum of Groups $\mathrm{P}$ and $\mathrm{S}$. This implies that Group $\mathrm{T}$ consists of 8 parts, if the unit $\mathrm{g} / \mathrm{t}$ is assumed to equal the unit $\mathrm{g} / \mathrm{m}^{3}$. It is possible, however, to assume that Group $\mathrm{T}$ consists of 5 parts which are separated at $30,20,3$, and $0.5 \mathrm{~g} / \mathrm{t}$ (Fig.12). This partitioning is the same as Group P. The cumulative tonnage, accordingly, can be estimated by the combination of three exponential functions showing the high $(>30 \mathrm{~g} / \mathrm{t})$, middle $(30-3 \mathrm{~g} / \mathrm{t})$ and low $(<0.5 \mathrm{~g} / \mathrm{t})$ grade parts as follows:

$$
\begin{aligned}
T_{\mathrm{All}} / \mathrm{kt}= & \exp \{\ln 10 \cdot(-3.94-0.0162 x)\}+\exp \{\ln 10 \cdot(6.39-0.150 x)\} \\
& +\exp \{\ln 10 \cdot(7.18-2.18 x)\} . \cdots \cdots \cdots \cdots \cdots \cdots
\end{aligned}
$$

Comparing the equation with that of Group P, the first term is the same, the second term is somewhat gentle, and the third term is steep. The latter two small differences are due to the fact that Group $\mathrm{S}$ is included. The correlation coefficient between the actual and estimated values is 0.993 (Table 4).

\section{Critical Grades}

As shown in Figs.8-12, the relations between grades and cumulative tonnages of gold resources are convex downwards on the $x-\log T(x)$ diagram. The same trend is found in the grade-tonnage relation of 2233 Au-bearing deposits stored in MIS (Mine Information System) data of Sumitomo Metal Mining Co. Ltd. (Fig.13), and hence gold resources were concluded to be sufficiently optimistic ${ }^{3)}$ by reason of the trend. However, the relation of the MIS data should be approximated by two exponential functions showing the high $(>30 \mathrm{~g} / \mathrm{t})$ and middle $(13-5 \mathrm{~g} / \mathrm{t})$ grade parts as follows:

$T_{\text {MIS-AllAu }}=\exp \{\ln 10 \cdot(1.39-0.013 x)\}+\exp \{\ln 10 \cdot(4.01-0.151 x)\}$. In this case, the correlation coefficient between the actual and estimated cumulative tonnages is 0.980 . If the low $(<2.5 \mathrm{~g} / \mathrm{t})$ grade part is also included for the approximation as follows:

$$
\begin{aligned}
T_{\text {MIS-AllAu }}= & \exp \{\ln 10 \cdot(1.39-0.013 x)\}+\exp \{\ln 10 \cdot(4.01-0.151 x)\}, \\
& +\exp \{\ln 10 \cdot(4.39-0.381 x)\} \quad \cdots \cdots \cdots \cdots
\end{aligned}
$$

the correlation coefficient is 0.989 . If the data are limited to1806 deposits which produce mainly gold, the grade-tonnage relation is well approximated by two exponential functions corresponding to the high $(>30 \mathrm{~g} / \mathrm{t})$ and middle-low $(<13 \mathrm{~g} / \mathrm{t})$ grade parts as follows: 


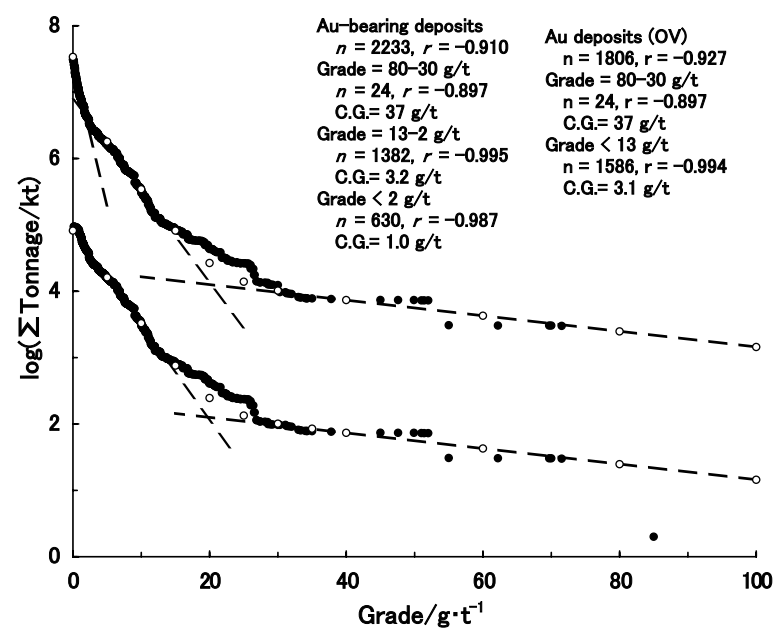

Fig. 13 Grade-cumulative tonnage relations of gold deposits stored in MIS. Upper and lower dot series correspond to all deposits producing gold mainly or accessorily, and deposits producing gold mainly. The lower dot series is shifted downwards by 1 unit in the vertical axis in order to avoid overlapping. Open circles show the grade-cumulative tonnage relations estimated by Equations (8) and (9)

$T_{\text {MIS-MainAu }}=\exp \{\ln 10 \cdot(1.34-0.012 x)\}$

$$
+\exp \{\ln 10 \cdot(3.91-0.142 x)\} . \cdots \cdots
$$

The correlation coefficient in this case is 0.990 .

One of the most important information given by the grade-tonnage model is the critical grade, by which resources are classified as optimistic or pessimistic. The present analysis indicates that the critical grades of the Chinese gold resources are 2.8, 0.20, 0.27, 0.10 and 0.20 for Groups Pm, Pa, P, S and T, respectively. On the other hand, the MIS data give the critical grades of 2.9 and $1.1 \mathrm{~g} / \mathrm{t}$ for the middle and low grade parts of the grade-tonnage relation of all gold deposits, respectively, and $3.1 \mathrm{~g} / \mathrm{t}$ for the deposits producing mainly gold.

In the MIS data, the critical grade of the middle grade part for all deposits is very similar to that of mainly gold-producing deposits. This fact suggests that the former value corresponds to mainly gold-producing deposits. The value is also similar to the critical grade of Group Pm, the deposits of which are primary in origin and produce mainly gold. It is concluded, therefore, that the critical grade of the primary-type and mainly gold-producing deposits is about $3 \mathrm{~g} / \mathrm{t}$. This value is almost equal to the lowest grade of the presently working gold mines whose deposits are primary.

The value obtained from the low-grade part of the MIS data is considered to indicate the critical grade for the deposits producing gold as an accessory metal. The value, however, is higher than the critical value of Group Pa. The reason of this difference is not clear at present. The proportions of mainly gold-producing deposits are similar in the MIS data and the Chinese data ( 81 and $82 \%$, respectively), and hence it is not considered to be one of the reasons.

The number of extremely low grade $\left(<0.1 \mathrm{~g} / \mathrm{m}^{3}\right)$ deposits of Group S (placer-type) is extremely few (only 4). Accordingly, the grade-tonnage diagram is flat in this part. The critical grade of Group $\mathrm{S}$ is the same as this value. This implies that the placer mines of the lowest grade are operated at the critical condition.

\section{Conclusions}

Gold deposits in China are classified into three independent groups and two summarized groups: primary-main $(\mathrm{Pm})$, primary-accessory $(\mathrm{Pa})$, placer $(\mathrm{S})$, primary $(\mathrm{P}=\mathrm{Pm}+\mathrm{Pa})$ and all data $(\mathrm{T}=\mathrm{P}+\mathrm{S})$, and analyzed statistically. Gold metal amount shows lognormal distribution in each of the groups. Grade of each of Groups Pm and Pa shows single populations, but that of Group S two populations. The low correlation between grades and metal amounts and the high correlation between tonnages and gold amounts indicate that metal amounts of deposits depend largely on tonnage, and scarcely on grades. The grade-cumulative tonnage relation of every group is approximated by the combination of two or three exponential functions. The critical grade of Group Pm is $3 g / t$, and is equal to that of the world gold resources of the same type. The critical grade of Group $S$ is $0.1 \mathrm{~g} / \mathrm{m}^{3}$. These values suggest that the mines with low grades are operated at the critical condition.

Acknowledgment We are grateful to Emeritus Prof. L. C. Hsu of University of Nevada-Reno who reviewed critically the manuscripts and gave many important comments. The work is partially supported by a Grand-in-Aid for the International Scientific Research (Nos. 06041027 and 10041136) sponsored by the Ministry of Education, Science and Culture of Japan.

\section{References}

1) D. P. Cox and D. Singer : U. S. Geol. Surv., Bull. 1693, (1986) p.379.

2) T. Shoji : MMIJ/IMM Joint Sym., (Kyoto, Japan, 1989), pp.109-114.

T) Shoji : 1st Intern. Conf. Processing Materials for Properties (ed. H. Henein and T. Oki), (The Minerals Metals \& Materials Soc., 1993), pp.463-466.

4) T. Shoji : Trans. Mat. Res. Soc., Jan., 18A(1994), 11-15.

5) T. Shoji : Jour. China Univ. Geosci., 12(2001), 45-53.

6) T. Shoji and X.-G. Meng : Proc. IAMG'98 (Intern. Assoc. Math. Geol.), (Ischia, Italy, 1998), pp.541-548.

7) D. Singer, D. P. Cox and L. J. Drew : U. S. Geol. Surv., Prof. Paper 907-A, (1975), pp.A1-A11.

8) J. Zhou, P. G. Flood and W. Li : Resource Geol., 50(2000), 53-64.

\section{中国金鉱床の品位一鉱量モデル}

\begin{abstract}
正 路 徹 也 ${ }^{1}$
中国の金資源を予測評価するために, 1600 以上の初成と次成の 鉱床を統計学的に解析した。解析の鉱床は, 初成で主成分 $(\mathrm{Pm})$, 初成で副成分 $(\mathrm{Pa})$, および砂鉱床 $(\mathrm{S})$ という 3 つの独立グループ と, 初成 $(\mathrm{P}=\mathrm{Pm}+\mathrm{Pa})$ および全体 $(\mathrm{T}=\mathrm{P}+\mathrm{S})$ という 2 つの統合グ ループに分けた。金量は, 各グループとも対数正規分布を示した。 金品位は, グループ Pm と Pa がそれぞれ単一の母集団を示すのに 対し, グループ S は 2 つの集団に分けられた。品位, 金量, 鉱 量の間の相関係数を見ると各鉱床の金量は鉱量に依存し，品位と
\end{abstract}

\section{孟憲 国 ${ }^{2}$}

はほとんど関係ない。各グループの品位と累積鉱量の関係は，2 るいは 3 つの指数関数の組合せで説明できる。それらから得られる 臨界品位は, グループ Pm が $2.8 \mathrm{~g} / \mathrm{t}$, グループ Pa が $0.20 \mathrm{~g} / \mathrm{t}$, グルー プ $\mathrm{S}$ が $0.10 \mathrm{~g} / \mathrm{m}^{3}$ である。これらの值は, 中国における低品位の金 鉱床は臨界状態で操業されていることを意味する。

$\left[\begin{array}{l}\text { 1. 普通会員 工博 東京大学教授 新領域創成科学研究科 環境学専攻 } \\ \text { 2. pH.D. 暨南 生物工程系 (安索管理公司) } \\ \text { キーワード: 金, 中国, 資源, 予測, 品位, 鉱量 }\end{array}\right]$ 